\title{
Increased Accumulation of Intraneuronal Amyloid $\beta$ in HIV-Infected Patients
}

\author{
Cristian L. Achim • Anthony Adame • \\ Wilmar Dumaop • Ian P. Everall • Eliezer Masliah • \\ HNRC
}

Received: 15 January 2009 / Accepted: 25 February 2009/Published online: 17 March 2009

(C) The Author(s) 2009. This article is published with open access at Springerlink.com

\begin{abstract}
In recent years, human immunodeficiency virus (HIV)-infected patients under highly active anti-retroviral therapy (HAART) regimens have shown a markedly improved general clinical status; however, the prevalence of mild cognitive disorders has increased. We propose that increased longevity with HIV-mediated chronic inflammation combined with the secondary effects of HAART may increase the risk of early brain aging as shown by intraneuronal accumulation of abnormal protein aggregates like amyloid $\beta(\mathrm{A} \beta)$, which might participate in worsening the neurodegenerative process and cognitive impairment in older patients with HIV. For this purpose, levels and distribution of $\mathrm{A} \beta$ immunoreactivity were analyzed in the frontal cortex of 43 patients with HIV (ages 38-60) and HIV- age-matched controls. Subcellular localization of the A $\beta$-immunoreactive material was analyzed by double labeling and confocal
\end{abstract}

The San Diego HIV Neurobehavioral Research Center (HNRC) group is affiliated with the University of California, San Diego, the Naval Hospital, San Diego, and the Veterans Affairs San Diego Healthcare System, and includes: Director: Igor Grant, M.D.; Co-Directors: J. Hampton Atkinson, M.D., Ronald J. Ellis, M.D., Ph.D., and J. Allen McCutchan, M.D.; Center Manager: Thomas D. Marcotte, Ph.D.; Melanie Sherman; Naval Hospital San Diego: Braden R. Hale, M.D., M.P.H. (P.I.); Neuromedical Component: Ronald J. Ellis, M.D., Ph.D. (P.I.), J. Allen McCutchan, M.D., Scott Letendre, M.D., Edmund Capparelli, Pharm.D., Rachel Schrier, Ph.D.; Jennifer Marquie-Beck; Terry Alexander, R.N.; Janis Durelle; Neurobehavioral Component: Robert K. Heaton, Ph.D. (P.I.), Mariana Cherner, Ph.D., Steven Paul Woods, Psy.D., David J. Moore, Ph.D.; Matthew Dawson; Neuroimaging Component: Terry Jernigan, Ph.D. (P.I.), Christine FennemaNotestine, Ph.D., Sarah L. Archibald, M.A., John Hesselink, M.D., Jacopo Annese, Ph.D., Michael J. Taylor, Ph.D., Brian Schweinsburg, Ph.D.; Neurobiology Component: Eliezer Masliah, M.D. (P.I.), Ian P. Everall, FRCPsych., FRCPath., Ph.D., Cristian L. Achim, M.D., Ph.D.; Neurovirology Component: Douglas Richman, M.D., (P.I.), David M. Smith, M.D.; International Component: J. Allen

McCutchan, M.D., (P.I.); Developmental Component: Ian P. Everall, FRCPsych., FRCPath., Ph.D. (P.I.), Stuart Lipton, M.D., Ph.D.; microscopy and by immunono-electron microscopy (EM). Compared to HIV - cases, in HIV+ cases, there was abundant intracellular $A \beta$ immunostaining in pyramidal neurons and along axonal tracts. Cases with HIV encephalitis (HIVE) had higher levels of intraneuronal $\mathrm{A} \beta$ immunoreactivity compared to HIV+ cases with no HIVE. Moreover, levels of intracellular $A \beta$ correlated with age in the group with HIVE. Double-labeling analysis showed that the $A \beta-$ immunoreactive granules in the neurons co-localized with lysosomal markers such as cathepsin-D and LC3. Ultrastructural analysis by immuno-EM has confirmed that in these cases, intracellular $A \beta$ was often found in structures displaying morphology similar to autophagosomes. These findings suggest that long-term survival with HIV might interfere with clearance of proteins such as $\mathrm{A} \beta$ and worsen neuronal damage and cognitive impairment in this population.

Clinical Trials Component: J. Allen McCutchan, M.D., J. Hampton Atkinson, M.D., Ronald J. Ellis, M.D., Ph.D., Scott Letendre, M.D.; Participant Accrual and Retention Unit: J. Hampton Atkinson, M.D. (P.I.), Rodney von Jaeger, M.P.H.; Data Management Unit: Anthony C. Gamst, Ph.D. (P.I.), Clint Cushman (Data Systems Manager), Daniel R. Masys, M.D. (Senior Consultant); Statistics Unit: Ian Abramson, Ph.D. (P.I.),Florin Vaida, Ph.D., Christopher Ake, Ph.D.

C. L. Achim • I. P. Everall

Department of Psychiatry, University of California,

San Diego, CA, USA

C. L. Achim • W. Dumaop • E. Masliah Department of Pathology, University of California, San Diego, CA, USA

A. Adame $\cdot$ E. Masliah $(\triangle)$

Department of Neurosciences, University of California,

9500 Gilman Dr., La Jolla,

San Diego, CA 92093-0624, USA

e-mail: emasliah@UCSD.edu 
Keywords HIV A AIDS · amyloid · encephalitis · protein aggregation

\section{Introduction}

In the age of highly active antiretroviral therapy (HAART), the survival of patients with AIDS has increased, and the proportion of HIV patients over the age of 50 has become significant. A recent study (Valcour et al. 2004a) found that individuals over 50 years of age represent $11 \%$ of the HIV cases registered by the Centers for Disease Control and Prevention (CDC). Data from the Hawaii cohort suggest an association between increased neurocognitive impairment in older HIV patients compared with younger controls (Valcour et al. 2004a, b, c, 2005; Valcour and Shiramizu 2004). Moreover, in a study in Western Pennsylvania (Becker et al. 2004), the prevalence of cognitive disorder among HIV-positive patients over 50 years of age was significantly higher than in younger individuals. Factors leading to this association may include vascular pathology, age-related immunological changes, and limited compensatory brain capacity. This suggests that chronic HIV infection and aging have similar effects on global cognitive functioning. Progressive brain dysfunction associated with aging has been linked to synapto-dendritic damage, reduced neurotransmitter production, and increased neuro-inflammatory reactivity associated with formation of radical oxygen species (Agrawal et al. 2006; Platenik et al. 2001; Price et al. 2006; Reynolds et al. 2007; Visalli et al. 2007).

Also contributing to the neuronal injury in older HIV patients might be the chronic permanence of HIV in the CNS. The HIV reservoir in the brain is known to be more difficult to reach because of the limited penetrance of HAART, emergence of resistant species, and viral escape (Dunfee et al. 2006; Langford et al. 2004).

Thus, despite the beneficial effects of HAART at suppressing viral load peripherally, the continued prevalence of moderate neurocognitive alterations in patients with HIV (Ances et al. 2008; Tozzi et al. 2007) might be related to the persistence of HIV in the CNS. Therefore, HIV encephalitis (HIVE) has shifted from a subacute neuro-inflammatory condition with abundant multinucleated giant cells to a more chronic and protracted condition with moderate astrogliosis, microgliosis, and viral load but more extensive neurodegeneration.

HAART has modified the patterns of HIV-related neuropathology and clinical manifestations in the past 10 years with the emergence of new variants of HIV encephalopathy (Everall et al. 2006). A paramount co-pathogenic factor in the long-term survival of patients with HIV on HAART is age. During aging, there is a failure in the handling and clearance of misfolded proteins such as $\mathrm{A} \beta$ and $\alpha$ - synuclein. Misfolded proteins can be cleared via lysosomal (e.g., autophagy) and non-lysosomal pathways (e.g., proteasome; Williams et al. 2006). In Alzheimer's disease (AD) and other neurodegenerative disorders, this is manifested by increased accumulation of $A \beta$ into toxic oligomers (Barghorn et al. 2005; Deshpande et al. 2006; Glabe 2008; Shin et al. 2008; Standridge 2006; Tsigelny et al. 2008; Watson et al. 2005; White et al. 2005; Wisniewski and Konietzko 2008; Yoshiike et al. 2003; Selkoe 2008). Recent studies have suggested that in addition to the extracellular deposition of $\mathrm{A} \beta$, in $\mathrm{AD}$, a smaller but significant fraction might accumulate intraneuronally (Arvanitis et al. 2007; Cuello 2005; Cuello and Canneva 2008; Echeverria and Cuello 2002; Grant et al. 2000; Green et al. 2005). Previous studies have shown that in aged HIV patients, there is increased amyloid deposition and plaque formation (Daily et al. 2006; Green et al. 2005; Rempel and Pulliam 2005). However, it was unclear what is the earliest site for $\mathrm{A} \beta$ accumulation in patients with HIV and how this might be related to the alterations in protein handling during aging. For this purpose, patterns of intracellular $A \beta$ accumulation and its relationship with lysosomal clearance were analyzed in HIV cases ranging in age from 38-60 years old. Our results indicate that in this population, there is increased intraneuronal $A \beta$ accumulation in lysosomalautophagic structures. These findings suggest that longerterm survival with HIV might interfere with clearance of proteins such as $A \beta$ that might worsen neuronal damage and cognitive impairment in this population.

\section{Materials and methods}

Subjects and neuropathological assessment For the present study, we included a total of 43 HIV+ cases from the HIV Neurobehavioral Research Center and California NeuroAIDS Tissue Network at the University of California San Diego. Cases had neuromedical and neuropsychological examinations within a median of 12 months before death. Most cases died as a result of acute bronchopneumonia or septicemia, and autopsy was performed within $24 \mathrm{~h}$ of death. Autopsy findings were consistent with AIDS, and the associated pathology was most frequently due to systemic CMV, Kaposi sarcoma, and liver disease. Subjects were excluded if they had a history of CNS opportunistic infections or non-HIV-related developmental, neurologic, psychiatric, or metabolic conditions that might affect CNS functioning (e.g., loss of consciousness exceeding $30 \mathrm{~min}$, psychosis, substance dependence). In all cases, neuropathological assessment was performed in paraffin sections from the frontal, parietal, temporal cortices, hippocampus, basal ganglia, and brainstem stained with H\&E or immunolabeled with antibodies against p24 and GFAP (Achim 
et al. 1993; Masliah et al. 1992). The diagnosis of HIVE was bases on the presence of microglial nodules, astrogliosis, HIV p24-positive cells, and myelin pallor. Additional analysis was performed with a subset of five age-matched (non-HIV) cases from the UCSD-Medical center Autopsy Service.

Immunocytochemical analysis and image analysis To further evaluate the patterns of $A \beta$ immunoreactivity in the brains of patients with HIV, briefly as previously described (Rockenstein et al. 2005) vibratome sections from the midfrontal cortex (40 $\mu \mathrm{m}$ thick) were incubated overnight at $4^{\circ} \mathrm{C}$ with the mouse monoclonal antibody against $\mathrm{A} \beta$ (clone 4G8; 1:600, Senetek, Napa, CA, USA) or with the antibody against the $\mathrm{N}$ terminus of $\mathrm{A} \beta$ (aa 1-16; clone $82 \mathrm{E} 1$; ImmunoBiological Laboratories, Gunma, Japan) followed by incubation with secondary biotinylated anti-mouse $\mathrm{IgG}$, followed by $\mathrm{ABC}$ and DAB. Sections were transferred to SuperFrost slides (Fisher Scientific, Tustin, CA, USA) and mounted under glass coverslips with anti-fading media (Vector Laboratories, Burlingame, CA, USA). All sections were processed under the same standardized conditions. From each case, an average of 50 neurons were imaged, and digital files were analyzed with the Image Quant system. Three immunolabeled sections were analyzed per case, and the average of individual measurements was used to calculate group means. Additional confirmation of the intracellular amyloid labeling was performed utilizing the Thioflavine-S staining in the vibratome sections (Rockenstein et al. 2001).

Double immunolabeling and confocal laser microscopy To evaluate the co-localization between $\mathrm{A} \beta$ immunoreactivity and lysosomal markers, double immunocytochemical analysis was performed (Belinson et al. 2008). For this purpose, vibratome sections were immunolabeled with a monoclonal antibody against $\mathrm{A} \beta$ (clone 4G8; 1:600, Senetek, Napa, CA, USA) detected with FITC-conjugated secondary antibodies (1:75, Vector Laboratories) and the antibodies against cathepsin-D, Lamp2, and Rab5 (1:500, Dako, Carpinteria, CA, USA) detected with the Tyramide Signal Amplification ${ }^{\text {TM}}$-Direct (Red) system (1:100, NEN Life Sciences, Boston, MA, USA; Pickford et al. 2008). All sections were processed simultaneously under the same conditions, and experiments were performed twice to assess reproducibility. Sections were imaged with a Zeiss $63 \mathrm{X}$ (N.A. 1.4) objective on an Axiovert 35 microscope (Zeiss, Germany) with an attached MRC1024 LSCM system (BioRad). To confirm the specificity of primary antibodies, control experiments were performed where sections were incubated overnight in the absence of primary antibody (deleted) or preimmune serum and primary antibody alone.

Immunoelectron microscopy analysis Briefly, vibratome sections immunostained as described above with the 4G8 antibody or a nonimmune IgG were fixed in $0.25 \%$ glutaraldehyde and 3\% paraformaldehyde in $0.1 \mathrm{M}$ cacodylate buffer (pH 7.4) and then pre-embedded with 50\% Durcupan epoxy resin, and $50 \%$ ethanol (dry) for $30 \mathrm{~min}$. Samples were then embedded in Durcupan mix epoxy resin and polymerized under a vacuum at $60^{\circ} \mathrm{C}$ for $48 \mathrm{~h}$. After the resin was polymerized, tissues were mounted into plastic cylinders, sectioned with an ultra microtome (Reichert Ultracut E) at $60 \mathrm{~nm}$ thickness and collected in copper grids for ultrastructural analysis. The immunostained grids were post-stained using saturated uranyl acetate solution in 50\% ethanol for $20 \mathrm{~min}$ at room temperature, washed in distilled water, and placed in bismuth nitrate solution for $10 \mathrm{~min}$ followed by a final wash in deionized water. The immunolabeled grids were analyzed with a Zeiss EM10 electron microscope and electron micrographs obtained at a magnification of 35,000 .

Statistical analysis All the analyses were conducted on blind-coded samples. After the results were obtained, the code was broken, and data were analyzed with the StatView program (SAS Institute, Cary, NC, USA). Comparisons among groups were performed with unpaired Student's $T$ test, Chi square analysis and simple linear regression analysis. All results were expressed as mean \pm SEM.

\section{Results}

Intraneuronal accumulation of $A \beta$ in HIV patients A total of 48 cases were included, of which 43 were HIV seropositive, and five were HIV seronegative (Table 1). The age

Table 1 Summary of demographic and pathological findings

\begin{tabular}{lccccccc}
\hline Group & $\begin{array}{l}\text { Number } \\
(N)\end{array}$ & $\begin{array}{l}\text { Gender } \\
\text { M/F }\end{array}$ & $\begin{array}{l}\text { Risk factor } \\
\text { MM/DU/other }\end{array}$ & $\begin{array}{l}\text { Age mean } \\
\text { (years) }\end{array}$ & $\begin{array}{l}\text { Age range } \\
\text { (years) }\end{array}$ & $\begin{array}{l}\text { Postmortem } \\
\text { interval (h) }\end{array}$ & $\begin{array}{l}\text { Cases with } \\
\text { intracellular A } \beta\end{array}$ \\
\hline HIV+, no HIVE & 18 & $15 / 3$ & $12 / 5 / 1$ & $49 \pm 1.5$ & $38-60$ & $18 \pm 2$ & $7 / 18(38 \%)$ \\
HIV+ Yes HIVE & 25 & $21 / 4$ & $16 / 9 / 0$ & $47 \pm 1$ & $39-57$ & $19 \pm 2$ & $18 / 25(72 \%)$ \\
HIV- & 5 & $4 / 1$ & $0 / 1 / 4$ & $47 \pm 2$ & $38-55$ & $15 \pm 2$ & $0 / 25(8 \%)$ \\
\hline
\end{tabular}




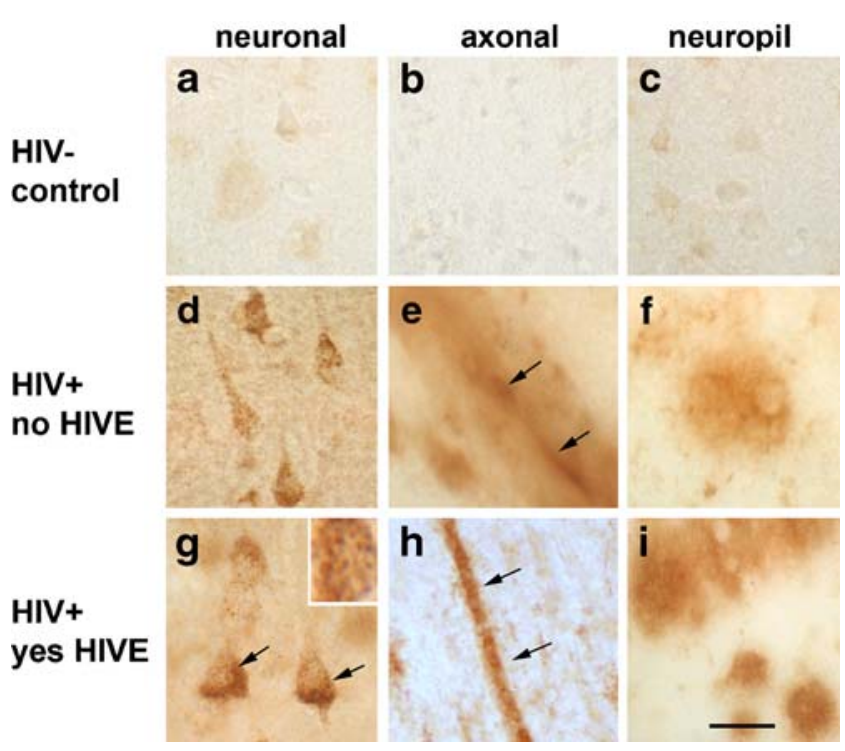

Fig. 1 Patterns of $A \beta$ immunoreactivity in control and HIV+ cases. Panels are from the frontal cortex immunostained with the monoclonal antibody 4G8. a-c In an age-matched control HIV- case (42 year old) the neuronal cell bodies (a), axons in the white matter (b), and neuropil (c) are devoid of amyloid deposits. d-f Examples of intraneuronal (d) granular $\mathrm{A} \beta$ immunoreactivity in an older HIV+ case (47 year old). A $\beta$ deposits can be found in axons (e) and in the neuropil (f) as diffuse plaques. $\mathbf{g}$-i Examples of intraneuronal (g) and axonal (h) A $\beta$ immunoreactivity (arrows) in an older HIV + case (50 year old) with HIVE. The inset shows in greater detail the punctate appearance of the intraneuronal $A \beta$ immunostaining. Diffuse amyloid plaques (i) were also detected in a few cases. Bar $=10 \mu \mathrm{m}$

range varied between 38 and 60 years with a mean of $48 \pm$ 2 years. Of the $43 \mathrm{HIV}$ cases, 18 had no significant opportunistic infections or HIVE, and the other 25 had HIVE. Immunocytochemical analysis with the antibody against $\mathrm{A} \beta$ (4G8 clone) showed that compared to HIVcontrols (Fig. 1A-C), in seven out of $18 \mathrm{HIV}+$ cases (38\%) with no HIVE, there was intraneuronal immunolabeling

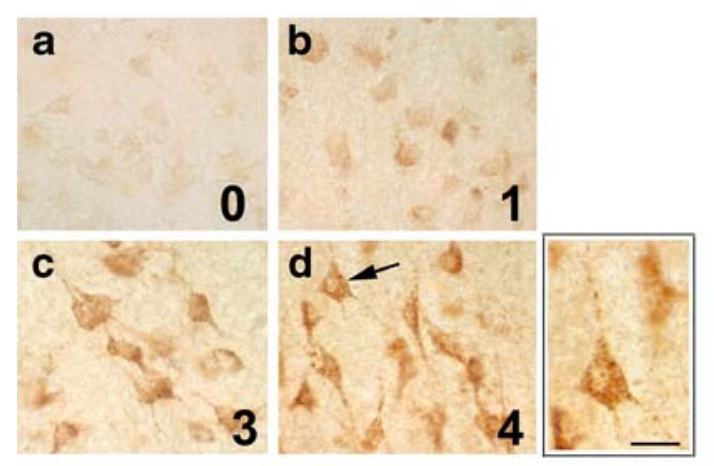

Fig. 2 Levels of intraneuronal $A \beta$ immunoreactivity in older HIV+ cases. Images are from the frontal cortex immunostained with the monoclonal antibody 4G8. a-d Examples of the various levels (0-4) of intraneuronal A $\beta$ immunoreactivity in HIV+ cases; the arrow indicates
(Fig. 1D). In contrast, in cases with HIVE, intraneuronal $\mathrm{A} \beta$ immunoreactivity was observed in 18 out of the 25 cases $(72 \%$; Fig. $1 \mathrm{G})$. This difference was significant by Chi square analysis $\left(X^{2}=4.7, p=0.029\right)$. The $\mathrm{A} \beta$ immunostaining was observed in pyramidal neurons in layers $2-3$ and 5 , had a granular cytoplasmic appearance that was concentrated in the neuronal cell body (Figs. 1D, G; 2B-E), although in some cases, extended to the axons (Fig. 1E, H) and dendrites (Fig. 2D). In the five control cases, there was very low or no detectable intracellular $A \beta$ immunostaining (Figs. 1A-C, 2E). Image analysis of the levels of intracellular $A \beta$ immunostaining in the individual cases showed significantly higher levels in the HIVE compared to HIV+ cases without HIVE ( $t$ test, $p=0.005$; Fig. 2 ). In one of the $\mathrm{HIV}+$ cases with no apparent HIVE (Fig. 1F) and in two of the cases with HIVE, there was evidence of extracellular $\mathrm{A} \beta$ deposition (Fig. 1I). The plaques had a diffuse appearance and in some cases surrounded neuronal cell bodies or were observed along axonal tracts (Fig. 3A-C). Although these diffuse plaques were similar to those observed in $\mathrm{AD}$, no abundant neuritic plaques or tangles were detected, thus ruling out the possibility of AD in these cases. Similar results were observed with the antibody against the $N$ terminus of $\mathrm{A} \beta$ (82E1 clone) and with thioflavine-S (Fig. 3D-F). Linear regression analysis showed that there was a significant correlation between the levels of intracellular $A \beta$ immunoreactivity and age in the HIV+ group with HIVE (Fig. 4A), but no correlation was observed in the HIV+ group with no HIVE (Fig. 4 B).

\section{Co-localization of lysosomal markers with the intraneuronal} $A \beta$ in the brains of HIV patients Given the punctate cytoplasmic characteristics of the intraneuronal $A \beta$ immunoreactivity in the HIV cases and that previous studies have suggested in experimental models that this might be localized

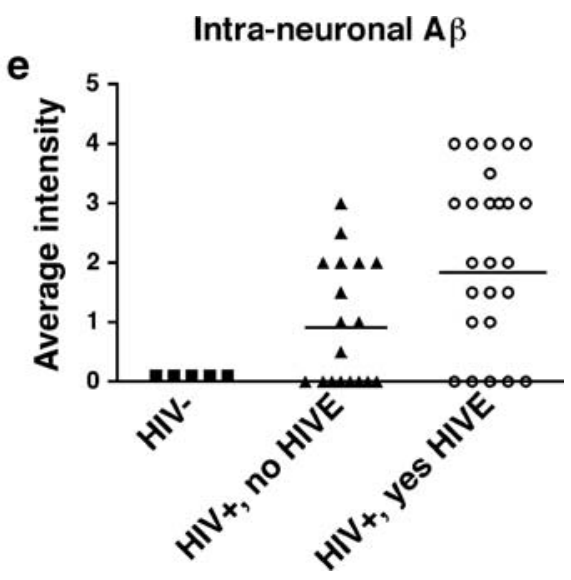

the enlarged image to the left displaying punctate appearance. e Compared to HIV+ with no HIVE, in cases with HIVE, there was an increase in the levels of intraneuronal $\mathrm{A} \beta$ immunoreactivity. $\mathrm{Bar}=5 \mu \mathrm{m}$ 
Fig. 3 Laser confocal microscopy imaging of the amyloid deposits in HIV+ cases.

Examples are from the frontal cortex. a No evidence of amyloid deposits in HIV- agematched control; $\mathbf{b}$, $\mathbf{c}$ doublelabeling with antibodies against the neuronal markers NeuN (red) and $\mathrm{A} \beta$ (green) showing neuronal amyloid deposits (b, arrows) and diffuse plaques (c, amyl) in HIV+ cases. d-f Comparative images in $\mathrm{HIV}-(\mathbf{d})$ and HIV+ (e, f) cases stained with thioflavine $\mathrm{S}$. Bar $=10 \mu \mathrm{m}$
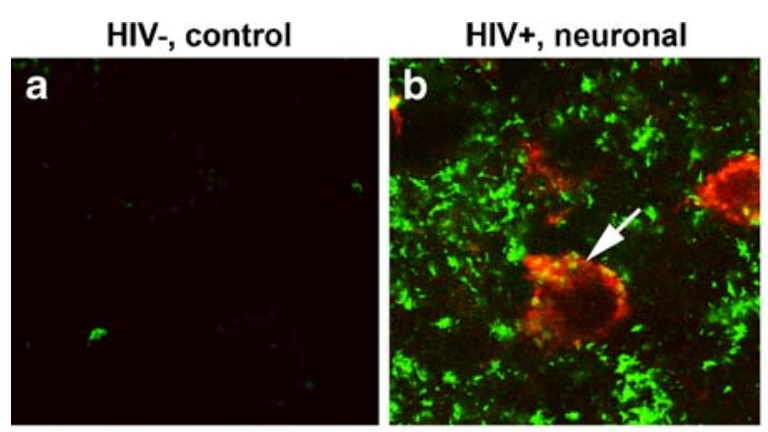

HIV+, diffuse amyloid
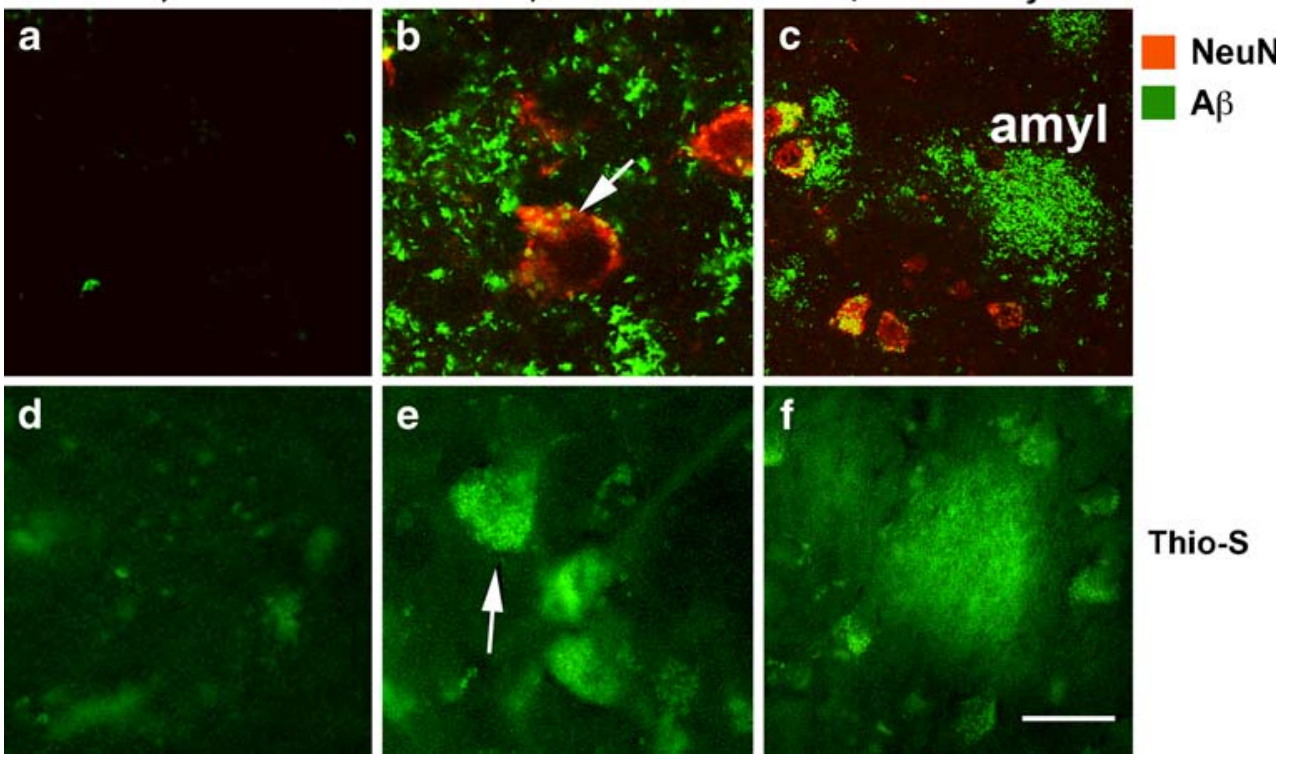

Thio-S

in lysosomal structures, double labeling studies were performed. By confocal microscopy, the A $\beta$-immunoreactive structures co-localized with the lysosomal markers cathepsinD (Fig. 5D-F) and LAMP2 (Fig. $5 \mathrm{G}-\mathrm{I}$ ). Moreover, the $\mathrm{A} \beta$-immunolabeled granular bodies co-localized with the autophagy marker LC3 (Fig. 5J-L). Overall, these granular structures were enlarged and clustered; in contrast, in control cases, discrete cathepsin-D lysosomal structures were identified that showed no $\mathrm{A} \beta$ immunoreactivity (Fig. $5 \mathrm{~A}-\mathrm{C}$ ).

To further investigate the intracellular localization of $\mathrm{A} \beta$, immunolabeled vibratome sections were analyzed by electron microscopy. Compared to control cases (Fig. 6A), in the HIV cases with intraneuronal $\mathrm{A} \beta$ immunoreactivity, aggregates were observed associated with structures reminiscent of lysosomes and autophagolysosomes in the cell body and in axonal structures (Fig. 6B, C).

\section{Discussion}

The present study showed that in HIV patients, there is a prominent intraneuronal accumulation of $A \beta$ associated with lysosomal structures. The intraneuronal $A \beta$ was more abundant in patients with HIVE compared to HIV cases with no significant pathology, and in the group with HIVE, the levels of intracellular $A \beta$ increased with age. These findings suggest that long-term survival with HIV might interfere with clearance of proteins such as $A \beta$ that might worsen neuronal damage and cognitive impairment in this population. Previous studies have shown in older HIV+ patients the presence of extracellular amyloid deposits similar to those detected in patients with AD (Green et al. 2005; Rempel and Pulliam 2005).

The first study to identify changes similar to mild AD was reported by Esiri et al. (1998) who found $A \beta$ plaques in HIV patients by using argyrophilic and thioflavine stainings. Another study using a more comprehensive methodology that included staining with the 4G8 antibody, Congo red, and Thioflavine-S (Izycka-Swieszewska et al. 2000) showed that in 15 AIDS cases (five with HIVE), three had perivascular plaques positive for 4G8 but not Congo Red or ThioflavineS. Based on these findings, the authors concluded that the neurodegeneration associated with HIV infection could be primarily of vascular origin. Our results suggest that while
Fig. 4 Linear regression analysis between intracellular $\mathrm{A} \beta$ and age. a In cases with HIVE, there was a significant correlation. b In cases with no HIVE, there was no significant correlation
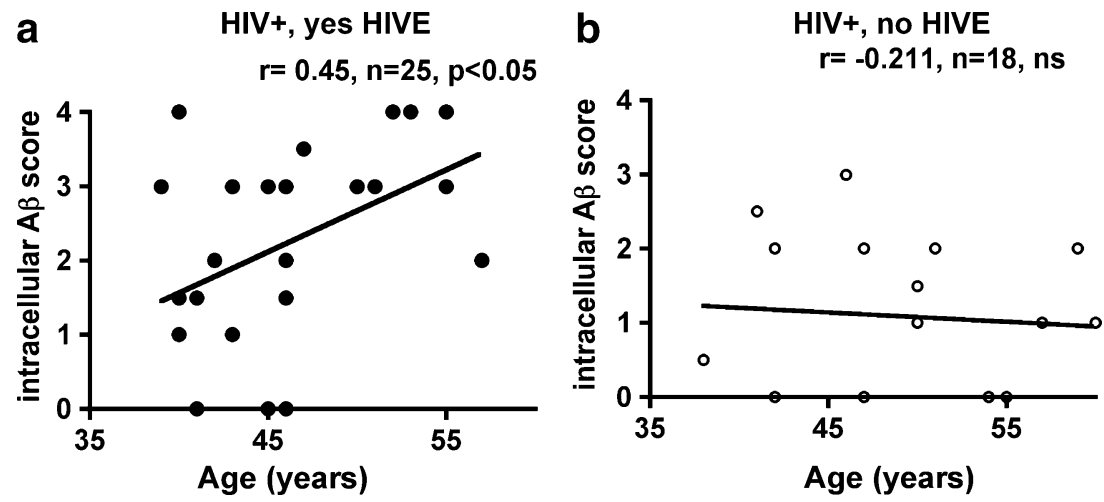
Fig. 5 Laser confocal

microscopy imaging of the intraneuronal $A \beta$ and lysosomal markers in older HIV+ cases.

Sections are from the frontal cortex double labeled with the $\mathrm{A} \beta$ (4G8) antibody (green) and lysosomal proteins cathepsin-D, LAMP2, and LC3 (red). a-c HIV- control case. d-I Co-localization (arrows) of intraneuronal $\mathrm{A} \beta$ and cathepsinD $(\mathbf{d}-\mathbf{f})$, LAMP2 $(\mathbf{g}-\mathbf{i})$, or LC3 $(\mathbf{j}-\mathbf{l})$ in an $\mathrm{HIV}+$ case.

Bar $=5 \mu \mathrm{m}$
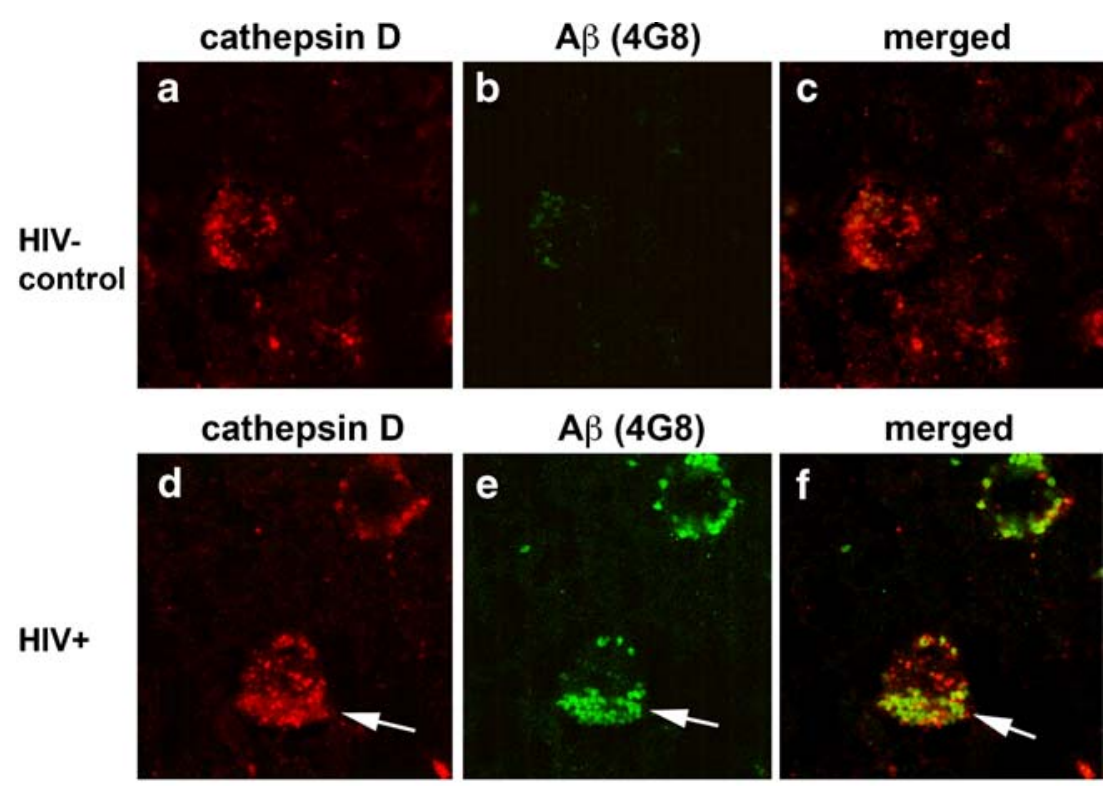

$A \beta(4 G 8)$
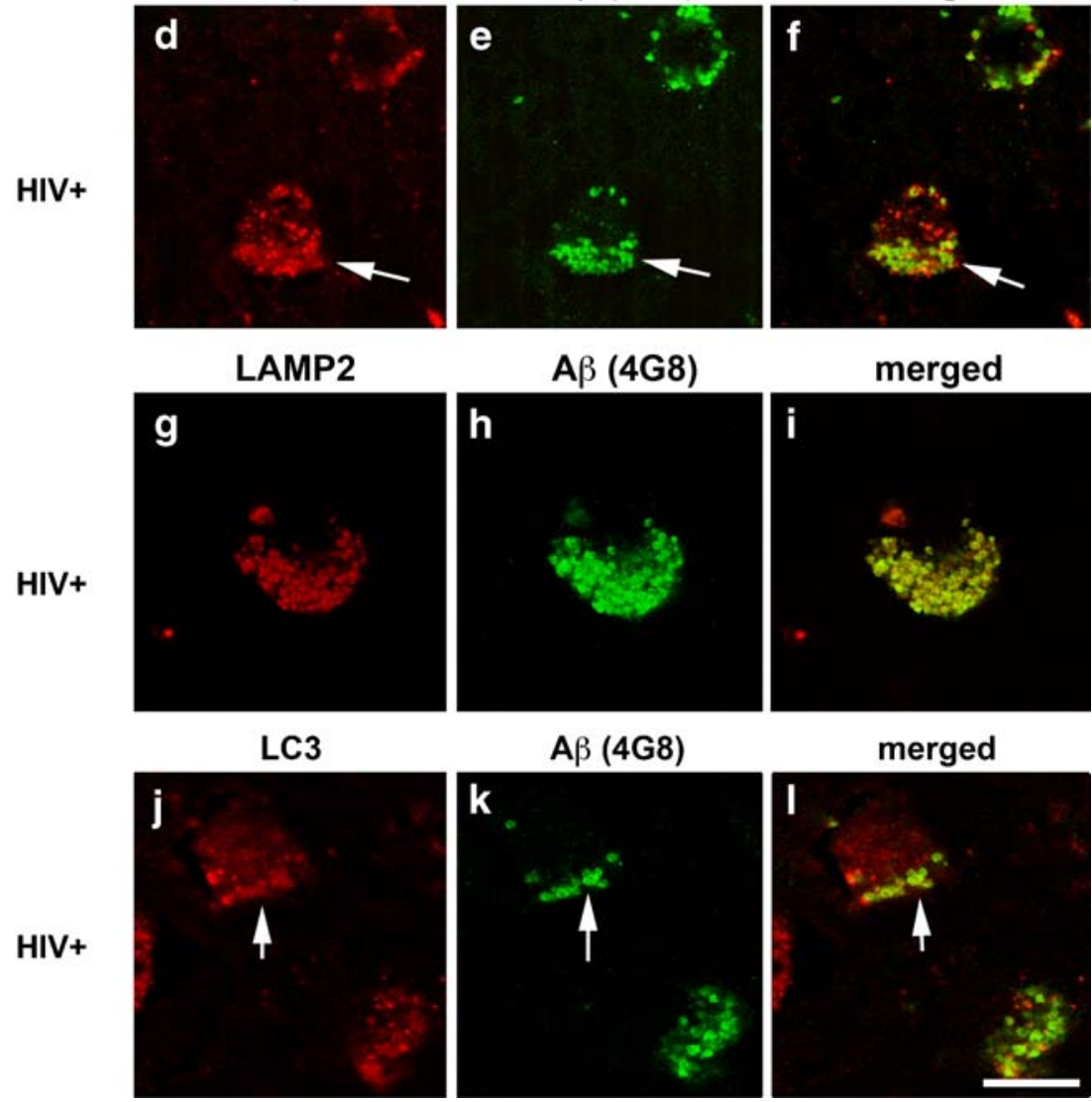
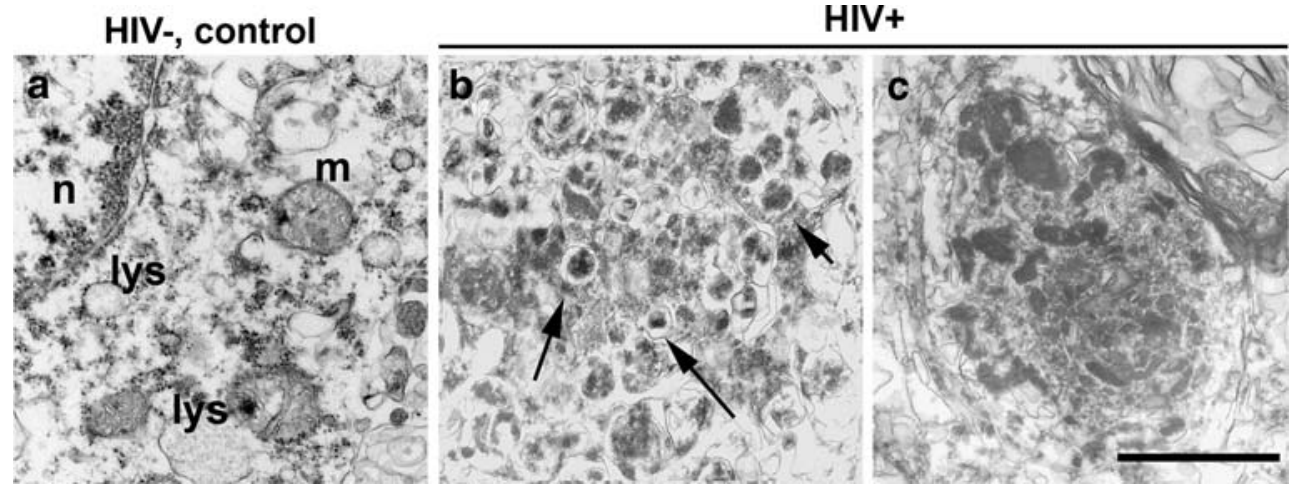

Fig. 6 Ultrastructural analysis of the $A \beta$ deposits in HIV+ cases. Sections from the frontal cortex were immunostained pre-embedding with 4G8 and analyzed with the electron microscope. a In a control, HIVcase, evidence of preservation of neuronal organelles such as lysosomes (lys) and mitochondria (m). b In an HIV+ case, abnormal electrodense membrane-bounded organelles (arrows) displaying A $\beta$ immunoreactivity accumulate in the neuronal cell body and axons. $\mathbf{c}$ Additional view of abnormal electrodense membrane-bounded organelles displaying intraneuronal $A \beta$ immunoreactivity in an $\mathrm{HIV}+$ case. $\mathrm{Bar}=2 \mu \mathrm{m}$ 
the vascular hypothesis may explain some of the plaques seen in the AIDS brains, given the intraneuronal accumulation and the neuronal origin of $A \beta$, this supports a possible cerebral source of the parenchymal amyloid.

$A \beta$ is the result of the proteolytic processing of APP by $\beta$ - and $\gamma$-secretases (Findeis 2007; Ghosh et al. 2005; Hoe and Rebeck 2008; Postina 2008; Russo et al. 2005; Thinakaran and Koo 2008; Vetrivel and Thinakaran 2006; Walsh et al. 2007; Wolfe 2006, 2008a, b). APP is ubiquitously distributed; in the CNS, APP is most abundantly produced by neurons and astroglial cells (Schmechel et al. 1988). Interestingly, the initial studies in the CNS of patients with HIV have focused on the levels of APP as a marker of neuronal injury. Several reports have described a significant increase in brain APP in AIDS cases, specifically in the axons of the subcortical white matter tracts. One leading theory is based on the inflammatory response in HIV infection of the brain parenchyma, where activated microglia are considered by many to be the likely source of mediators of disease that can promote overproduction and accumulation of APP (Adle-Biassette et al. 1999; Dickson et al. 1993). Among the brain macrophage-secreted factors mediating the overproduction of neuronal APP, a leading candidate is IL-1 (Stanley et al. 1994).

The association between the brain pathology characteristic of HIVE, including viral proteins and the presence of APP aggregates, often as intra-axonal globules, was reported in several studies (Giometto et al. 1997; Nebuloni et al. 2001; Raja et al. 1997). These results were further confirmed in the simian immunodeficiency virus (SIV) model of HIVE where Mankowski et al. have also found APP accumulation in degenerating axons (Mankowski et al. 2002). While the majority of these studies show a strong correlation between the topography of HIV-associated pathology and degenerating axons, suggesting a more local, intraparenchymal effect on APP accumulation, some investigators disagree. In one of the first studies of APP in the HIV brain, Scaravilli and colleagues (An et al. 1997) did not find a good correlation between APP and microgliosis and concluded that the axonal degeneration in HIV infection, may be due to systemic factors (e.g. cytokines).

The mechanisms through which HIV infection in the CNS might lead to increased accumulation of $A \beta$ are not completely clear. Recent studies suggest that HAART resistance, chronic HIV infection, HAART toxicity and reduced clearance of misfolded proteins might play a role (Hult et al. 2008). A $\beta$ is degraded by proteases such as neprilysin, insulin-degrading enzyme, and endothelin (Eckman and Eckman 2005; Miners et al. 2008; Nalivaeva et al. 2008; Wang et al. 2006). The HIV Tat protein has been shown to interfere with neprilysin activity, and HAART has been shown to alter the metabolic routes for $A \beta$ and insulin processing (Daily et al. 2006; Nath and
Hersh 2005; Rempel and Pulliam 2005). Neprilysin is not only capable of degrading extracellular but also intracellular A $\beta$ (Spencer et al. 2008). While the clinical benefit in reducing viral burden is indisputable, HAART is also reported to induce metabolic dysregulation resulting in a syndrome of lipodystrophy (LD) in up to $83 \%$ of treated individuals (Carr et al. 1999). Features associated with LD include insulin resistance with hyperinsulinemia, centripetal lipohypertrophy with concurrent subcutaneous peripheral lipoatrophy, and hypertriglyceridemia. The metabolic complications underlying LD include insulin resistance.

Another important mechanism involved in the clearance of $A \beta$ is the authophagy pathway (Jellinger 2006; Jellinger and Stadelmann 2001; Li et al. 2007; Lunemann et al. 2007; Nixon 2007; Shacka et al. 2008; Wilson et al. 2004; Yu et al. 2004, 2005; Zheng et al. 2006). This lysosomal pathway has been shown to be defective in patients with HIV (Delhaye et al. 2007; Fredericksen et al. 2002; Levine and Sodora 2006; Talloczy et al. 2008), and recent studies in $\mathrm{AD}$ patients have shown that alterations in autophagy leads to increased intracellular and extracellular $A \beta$ (Pickford et al. 2008). Consistent with this possibility, in the present study, we showed the intracellular A $\beta$ co-localized with lysosomal markers and accumulated in structures reminiscent of lysosomes and abnormal autophagosomes.

In summary, in HIV patients, there is extensive intraneuronal accumulation of $A \beta$ suggesting that long-term survival with HIV might interfere with clearance of proteins such as $A \beta$ that might worsen neuronal damage and cognitive impairment in this population.

Support The study is supported by NIH grants MH076681, MH79881, MH45294, MH5974, MH58164, and DA12065, California NeuroAIDS Tissue Network U01 MH83506. The HIV Neurobehavioral Research Center (HNRC) is supported by Center award MH 62512 from NIMH.

Open Access This article is distributed under the terms of the Creative Commons Attribution Noncommercial License which permits any noncommercial use, distribution, and reproduction in any medium, provided the original author(s) and source are credited.

\section{References}

Achim CL, Heyes MP, Wiley CA (1993) Quantitation of human immunodeficiency virus, immune activation factors, and quinolinic acid in AIDS brains. J Clin Invest 91:2769-2775 doi:10.1172/ JCI116518

Adle-Biassette H, Chretien F, Wingertsmann L, Hery C, Ereau T, Scaravilli F, Tardieu M, Gray F (1999) Neuronal apoptosis does not correlate with dementia in HIV infection but is related to microglial activation and axonal damage. Neuropathol Appl Neurobiol 25:123-133 doi:10.1046/j.1365-2990.1999.00167.x

Agrawal L, Louboutin JP, Reyes BA, Van Bockstaele EJ, Strayer DS (2006) Antioxidant enzyme gene delivery to protect from HIV-1 
gp120-induced neuronal apoptosis. Gene Ther 13:1645-1656 doi:10.1038/sj.gt.3302821

An SF, Giometto B, Groves M, Miller RF, Beckett AA, Gray F, Tavolato B, Scaravilli F (1997) Axonal damage revealed by accumulation of beta-APP in HIV-positive individuals without AIDS. J Neuropathol Exp Neurol 56:1262-1268

Ances BM, Letendre SL, Alexander T, Ellis RJ (2008) Role of psychiatric medications as adjunct therapy in the treatment of HIV associated neurocognitive disorders. Int Rev Psychiatry 20:89-93 doi:10.1080/09540260701877670

Arvanitis DN, Ducatenzeiler A, Ou JN, Grodstein E, Andrews SD, Tendulkar SR, Ribeiro-da-Silva A, Szyf M, Cuello AC (2007) High intracellular concentrations of amyloid-beta block nuclear translocation of phosphorylated CREB. J Neurochem 103:216228

Barghorn S, Nimmrich V, Striebinger A, Krantz C, Keller P, Janson B, Bahr M, Schmidt M, Bitner RS, Harlan J, Barlow E, Ebert U, Hillen H (2005) Globular amyloid beta-peptide oligomer-a homogenous and stable neuropathological protein in Alzheimer's disease. J Neurochem 95:834-847 doi:10.1111/j.1471-4159.2005. 03407.x

Becker JT, Lopez OL, Dew MA, Aizenstein HJ (2004) Prevalence of cognitive disorders differs as a function of age in HIV virus infection. AIDS 18(Suppl 1):S11-S18 doi:10.1097/00002030200401001-00003

Belinson H, Lev D, Masliah E, Michaelson DM (2008) Activation of the amyloid cascade in apolipoprotein E4 transgenic mice induces lysosomal activation and neurodegeneration resulting in marked cognitive deficits. J Neurosci 28:4690-4701 doi:10.1523/ JNEUROSCI.5633-07.2008

Carr A, Samaras K, Thorisdottir A, Kaufmann GR, Chisholm DJ, Cooper DA (1999) Diagnosis, prediction, and natural course of HIV-1 protease-inhibitor-associated lipodystrophy, hyperlipidaemia, and diabetes mellitus: a cohort study. Lancet 353:2093-2099 doi:10.1016/S0140-6736(98)08468-2

Cuello AC (2005) Intracellular and extracellular Abeta, a tale of two neuropathologies. Brain Pathol 15:66-71

Cuello AC, Canneva F (2008) Impact of intracellular beta-amyloid in transgenic animals and cell models. Neurodegener Dis 5:146148 doi: $10.1159 / 000113686$

Daily A, Nath A, Hersh LB (2006) Tat peptides inhibit neprilysin. J Neurovirol 12:153-160 doi:10.1080/13550280600760677

Delhaye M, Gravot A, Ayinde D, Niedergang F, Alizon M, Brelot A (2007) Identification of a postendocytic sorting sequence in CCR5. Mol Pharmacol 72:1497-1507 doi:10.1124/mol.107.038422

Deshpande A, Mina E, Glabe C, Busciglio J (2006) Different conformations of amyloid beta induce neurotoxicity by distinct mechanisms in human cortical neurons. J Neurosci 26:60116018 doi:10.1523/JNEUROSCI.1189-06.2006

Dickson DW, Lee SC, Mattiace LA, Yen SH, Brosnan C (1993) Microglia and cytokines in neurological disease, with special reference to AIDS and Alzheimer's disease. Glia 7:75-83 doi:10.1002/glia.440070113

Dunfee R, Thomas ER, Gorry PR, Wang J, Ancuta P, Gabuzda D (2006) Mechanisms of HIV-1 neurotropism. Curr HIV Res 4:267-278 doi:10.2174/157016206777709500

Echeverria V, Cuello AC (2002) Intracellular A-beta amyloid, a sign for worse things to come? Mol Neurobiol 26:299-316 doi:10.1385/ $\mathrm{MN}: 26: 2-3: 299$

Eckman EA, Eckman CB (2005) Abeta-degrading enzymes: modulators of Alzheimer's disease pathogenesis and targets for therapeutic intervention. Biochem Soc Trans 33:1101-1105 doi:10.1042/ BST20051101

Esiri MM, Biddolph SC, Morris CS (1998) Prevalence of Alzheimer plaques in AIDS. J Neurol Neurosurg Psychiatry 65:29-33 doi:10.1136/jnnp.65.1.29
Everall IP, Salaria S, Atkinson JH, Young C, Corbeil J, Grant I, Masliah E (2006) Diminished somatostatin gene expression in individuals with HIV and major depressive disorder. Neurology 67:1867-1869 doi:10.1212/01.wnl.0000244436.04036.a2

Findeis MA (2007) The role of amyloid beta peptide 42 in Alzheimer's disease. Pharmacol Ther 116:266-286 doi:10.1016/ j.pharmthera.2007.06.006

Fredericksen BL, Wei BL, Yao J, Luo T, Garcia JV (2002) Inhibition of endosomal/lysosomal degradation increases the infectivity of human immunodeficiency virus. J Virol 76:11440-11446 doi:10.1128/JVI.76.22.11440-11446.2002

Ghosh AK, Kumaragurubaran N, Tang J (2005) Recent developments of structure based beta-secretase inhibitors for Alzheimer's disease. Curr Top Med Chem 5:1609-1622 doi:10.2174/ 156802605775009711

Giometto B, An SF, Groves M, Scaravilli T, Geddes JF, Miller R, Tavolato B, Beckett AA, Scaravilli F (1997) Accumulation of beta-amyloid precursor protein in HIV encephalitis: relationship with neuropsychological abnormalities. Ann Neurol 42:34-40 doi:10.1002/ana.410420108

Glabe CG (2008) Structural classification of toxic amyloid oligomers. J Biol Chem 283:29639-29643 doi:10.1074/jbc.R800016200

Grant SM, Ducatenzeiler A, Szyf M, Cuello AC (2000) Abeta immunoreactive material is present in several intracellular compartments in transfected, neuronally differentiated, P19 cells expressing the human amyloid beta-protein precursor. J Alzheimers Dis 2:207-222

Green DA, Masliah E, Vinters HV, Beizai P, Moore DJ, Achim CL (2005) Brain deposition of beta-amyloid is a common pathologic feature in HIV positive patients. AIDS 19:407-411 doi:10.1097/ 01.aids.0000161770.06158.5c

Hoe HS, Rebeck GW (2008) Regulated proteolysis of APP and ApoE receptors. Mol Neurobiol 37:64-72 doi:10.1007/s12035-008-8017-0

Hult B, Chana G, Masliah E, Everall I (2008) Neurobiology of HIV. Int Rev Psychiatry 20:3-13 doi:10.1080/09540260701862086

Izycka-Swieszewska E, Zoltowska A, Rzepko R, Gross M, BorowskaLehman J (2000) Vasculopathy and amyloid beta reactivity in brains of patients with acquired immune deficiency (AIDS). Folia Neuropathol 38:175-182

Jellinger KA (2006) Challenges in neuronal apoptosis. Curr Alzheimer Res 3:377-391 doi:10.2174/156720506778249434

Jellinger KA, Stadelmann C (2001) Problems of cell death in neurodegeneration and Alzheimer's Disease. J Alzheimers Dis 3:31-40

Langford D, Grigorian A, Hurford R, Adame A, Ellis RJ, Hansen L, Masliah E (2004) Altered P-glycoprotein expression in AIDS patients with HIV encephalitis. J Neuropathol Exp Neurol 63:1038-1047

Levine B, Sodora DL (2006) HIV and CXCR4 in a kiss of autophagic death. J Clin Invest 116:2078-2080 doi:10.1172/JCI29447

Li M, Chen L, Lee DH, Yu LC, Zhang Y (2007) The role of intracellular amyloid beta in Alzheimer's disease. Prog Neurobiol 83:131-139 doi:10.1016/j.pneurobio.2007.08.002

Lunemann JD, Schmidt J, Schmid D, Barthel K, Wrede A, Dalakas MC, Munz C (2007) Beta-amyloid is a substrate of autophagy in sporadic inclusion body myositis. Ann Neurol 61:476-483 doi:10.1002/ana.21115

Mankowski JL, Queen SE, Tarwater PM, Fox KJ, Perry VH (2002) Accumulation of beta-amyloid precursor protein in axons correlates with CNS expression of SIV gp41. J Neuropathol Exp Neurol 61:85-90

Masliah E, Achim CL, Ge N, DeTeresa R, Terry RD, Wiley CA (1992) Spectrum of human immunodeficiency virus-associated neocortical damage. Ann Neurol 32:321-329 doi:10.1002/ana. 410320304

Miners JS, Baig S, Palmer J, Palmer LE, Kehoe PG, Love S (2008) Abeta-degrading enzymes in Alzheimer's disease. Brain Pathol 18:240-252 doi:10.1111/j.1750-3639.2008.00132.x 
Nalivaeva NN, Fisk LR, Belyaev ND, Turner AJ (2008) Amyloiddegrading enzymes as therapeutic targets in Alzheimer's disease. Curr Alzheimer Res 5:212-224 doi:10.2174/156720508783954785

Nath A, Hersh LB (2005) Tat and amyloid: multiple interactions. AIDS 19:203-204 doi:10.1097/00002030-200501280-00013

Nebuloni M, Pellegrinelli A, Ferri A, Bonetto S, Boldorini R, Vago L, Grassi MP, Costanzi G (2001) Beta amyloid precursor protein and patterns of HIV p24 immunohistochemistry in different brain areas of AIDS patients. AIDS 15:571-575 doi:10.1097/00002030200103300-00005

Nixon RA (2007) Autophagy, amyloidogenesis and Alzheimer disease. J Cell Sci 120:4081-4091 doi:10.1242/jcs.019265

Pickford F, Masliah E, Britschgi M, Lucin K, Narasimhan R, Jaeger PA, Small S, Spencer B, Rockenstein E, Levine B, Wyss-Coray T (2008) The autophagy-related protein beclin 1 shows reduced expression in early Alzheimer disease and regulates amyloid beta accumulation in mice. J Clin Invest 118:2190-2199

Platenik J, Stopka P, Vejrazka M, Stipek S (2001) Quinolinic acid-iron (ii) complexes: slow autoxidation, but enhanced hydroxyl radical production in the Fenton reaction. Free Radic Res 34:445-459 doi:10.1080/10715760100300391

Postina R (2008) A closer look at alpha-secretase. Curr Alzheimer Res 5:179-186 doi:10.2174/156720508783954668

Price TO, Uras F, Banks WA, Ercal N (2006) A novel antioxidant $N$ acetylcysteine amide prevents gp120- and Tat-induced oxidative stress in brain endothelial cells. Exp Neurol 201:193-202 doi:10.1016/j.expneurol.2006.03.030

Raja F, Sherriff FE, Morris CS, Bridges LR, Esiri MM (1997) Cerebral white matter damage in HIV infection demonstrated using beta-amyloid precursor protein immunoreactivity. Acta Neuropathol 93:184-189 doi:10.1007/s004010050601

Rempel HC, Pulliam L (2005) HIV-1 Tat inhibits neprilysin and elevates amyloid beta. AIDS 19:127-135 doi:10.1097/00002030200501280-00004

Reynolds A, Laurie C, Mosley RL, Gendelman HE (2007) Oxidative stress and the pathogenesis of neurodegenerative disorders. Int Rev Neurobiol 82:297-325 doi:10.1016/S0074-7742(07)82016-2

Rockenstein E, Mallory M, Mante M, Sisk A, Masliaha E (2001) Early formation of mature amyloid-beta protein deposits in a mutant APP transgenic model depends on levels of Abeta(1-42). J Neurosci Res 66:573-582 doi:10.1002/jnr.1247

Rockenstein E, Schwach G, Ingolic E, Adame A, Crews L, Mante M, Pfragner R, Schreiner E, Windisch M, Masliah E (2005) Lysosomal pathology associated with alpha-synuclein accumulation in transgenic models using an eGFP fusion protein. $\mathrm{J}$ Neurosci Res 80:247-259 doi:10.1002/jnr.20446

Russo C, Venezia V, Repetto E, Nizzari M, Violani E, Carlo P, Schettini G (2005) The amyloid precursor protein and its network of interacting proteins: physiological and pathological implications. Brain Res Brain Res Rev 48:257-264 doi:10.1016/j. brainresrev.2004.12.016

Schmechel DE, Goldgaber D, Burkhart DS, Gilbert JR, Gajdusek DC, Roses AD (1988) Cellular localization of messenger RNA encoding amyloid-beta-protein in normal tissue and in Alzheimer disease. Alzheimer Dis Assoc Disord 2:96-111 doi:10.1097/ 00002093-198802020-00002

Selkoe DJ (2008) Soluble oligomers of the amyloid beta-protein impair synaptic plasticity and behavior. Behav Brain Res 192:106-113 doi:10.1016/j.bbr.2008.02.016

Shacka JJ, Roth KA, Zhang J (2008) The autophagy-lysosomal degradation pathway: role in neurodegenerative disease and therapy. Front Biosci 13:718-736 doi:10.2741/2714

Shin TM, Isas JM, Hsieh CL, Kayed R, Glabe CG, Langen R, Chen J (2008) Formation of soluble amyloid oligomers and amyloid fibrils by the multifunctional protein vitronectin. Mol Neurodegener 3:16 doi:10.1186/1750-1326-3-16
Spencer B, Marr RA, Rockenstein E, Crews L, Adame A, Potkar R, Patrick C, Gage FH, Verma IM, Masliah E (2008) Long-term neprilysin gene transfer is associated with reduced levels of intracellular Abeta and behavioral improvement in APP transgenic mice. BMC Neurosci 9:109 doi:10.1186/1471-2202-9-109

Standridge JB (2006) Vicious cycles within the neuropathophysiologic mechanisms of Alzheimer's disease. Curr Alzheimer Res 3:95108 doi: $10.2174 / 156720506776383068$

Stanley LC, Mrak RE, Woody RC, Perrot LJ, Zhang S, Marshak DR, Nelson SJ, Griffin WS (1994) Glial cytokines as neuropathogenic factors in HIV infection: pathogenic similarities to Alzheimer's disease. J Neuropathol Exp Neurol 53:231-238 doi:10.1097/ 00005072-199405000-00003

Talloczy Z, Martinez J, Joset D, Ray Y, Gacser A, Toussi S, Mizushima N, Nosanchuk J, Goldstein H, Loike J, Sulzer D, Santambrogio L (2008) Methamphetamine inhibits antigen processing, presentation, and phagocytosis. PLoS Pathog 4:e28 doi:10.1371/journal. ppat. 0040028

Thinakaran G, Koo EH (2008) Amyloid precursor protein trafficking, processing, and function. J Biol Chem 283:29615-29619 doi:10.1074/jbc.R800019200

Tozzi V, Balestra P, Bellagamba R, Corpolongo A, Salvatori MF, Visco-Comandini U, Vlassi C, Giulianelli M, Galgani S, Antinori A, Narciso P (2007) Persistence of neuropsychologic deficits despite long-term highly active antiretroviral therapy in patients with HIV-related neurocognitive impairment: prevalence and risk factors. J Acquir Immune Defic Syndr 45:174-182 doi:10.1097/ QAI.0b013e318042e1ee

Tsigelny IF, Crews L, Desplats P, Shaked GM, Sharikov Y, Mizuno H, Spencer B, Rockenstein E, Trejo M, Platoshyn O, Yuan JX, Masliah E (2008) Mechanisms of hybrid oligomer formation in the pathogenesis of combined Alzheimer's and Parkinson's diseases. PLoS One 3:e3135 doi:10.1371/journal.pone.0003135

Valcour V, Shiramizu B (2004) HIV-associated dementia, mitochondrial dysfunction, and oxidative stress. Mitochondrion 4:119-129 doi:10.1016/j.mito.2004.05.009

Valcour V, Shikuma C, Shiramizu B, Watters M, Poff P, Selnes O, Holck P, Grove J, Sacktor N (2004a) Higher frequency of dementia in older HIV-1 individuals: the Hawaii Aging with HIV-1 Cohort. Neurology 63:822-827

Valcour V, Shikuma C, Shiramizu B, Watters M, Poff P, Selnes OA, Grove J, Liu Y, Abdul-Majid KB, Gartner S, Sacktor N (2004b) Age, apolipoprotein E4, and the risk of HIV dementia: the Hawaii Aging with HIV Cohort. J Neuroimmunol 157:197-202 doi:10.1016/j.jneuroim.2004.08.029

Valcour VG, Shikuma CM, Watters MR, Sacktor NC (2004c) Cognitive impairment in older HIV-1-seropositive individuals: prevalence and potential mechanisms. AIDS 18(Suppl 1):S79S86 doi:10.1097/00002030-200401001-00012

Valcour VG, Shikuma CM, Shiramizu BT, Williams AE, Watters MR, Poff PW, Grove JS, Selnes OA, Sacktor NC (2005) Diabetes, insulin resistance, and dementia among HIV-1-infected patients. J Acquir Immune Defic Syndr 38:31-36 doi:10.1097/00126334200501010-00006

Vetrivel KS, Thinakaran G (2006) Amyloidogenic processing of betaamyloid precursor protein in intracellular compartments. Neurology 66:S69-S73 doi:10.1212/01.wnl.0000192107.17175.39

Visalli V, Muscoli C, Sacco I, Sculco F, Palma E, Costa N, Colica C, Rotiroti D, Mollace V (2007) N-acetylcysteine prevents HIV gp 120-related damage of human cultured astrocytes: correlation with glutamine synthase dysfunction. BMC Neurosci 8:106 doi:10.1186/1471-2202-8-106

Walsh DM, Minogue AM, Sala Frigerio C, Fadeeva JV, Wasco W, Selkoe DJ (2007) The APP family of proteins: similarities and differences. Biochem Soc Trans 35:416-420 doi:10.1042/ BST0350416 
Wang DS, Dickson DW, Malter JS (2006) Beta-amyloid degradation and Alzheimer's disease. J Biomed Biotechnol 2006:58406 doi:10.1155/JBB/2006/58406

Watson D, Castano E, Kokjohn TA, Kuo YM, Lyubchenko Y, Pinsky D, Connolly ES Jr, Esh C, Luehrs DC, Stine WB, Rowse LM, Emmerling MR, Roher AE (2005) Physicochemical characteristics of soluble oligomeric Abeta and their pathologic role in Alzheimer's disease. Neurol Res 27:869-881 doi:10.1179/016164105X49436

White JA, Manelli AM, Holmberg KH, Van Eldik LJ, Ladu MJ (2005) Differential effects of oligomeric and fibrillar amyloid-beta 1-42 on astrocyte-mediated inflammation. Neurobiol Dis 18:459-465 doi:10.1016/j.nbd.2004.12.013

Williams A, Jahreiss L, Sarkar S, Saiki S, Menzies FM, Ravikumar B, Rubinsztein DC (2006) Aggregate-prone proteins are cleared from the cytosol by autophagy: therapeutic implications. Curr Top Dev Biol 76:89-101 doi:10.1016/S0070-2153(06)76003-3

Wilson CA, Murphy DD, Giasson BI, Zhang B, Trojanowski JQ, Lee VM (2004) Degradative organelles containing mislocalized alpha-and beta-synuclein proliferate in presenilin-1 null neurons. J Cell Biol 165:335-346 doi:10.1083/jcb. 200403061

Wisniewski T, Konietzko U (2008) Amyloid-beta immunisation for Alzheimer's disease. Lancet Neurol 7:805-811 doi:10.1016/ S1474-4422(08)70170-4

Wolfe MS (2006) The gamma-secretase complex: membraneembedded proteolytic ensemble. Biochemistry 45:7931-7939 doi:10.1021/bi060799c
Wolfe MS (2008a) Gamma-secretase inhibition and modulation for Alzheimer's disease. Curr Alzheimer Res 5:158-164 doi:10. 2174/156720508783954767

Wolfe MS (2008b) Gamma-secretase: structure, function, and modulation for Alzheimer's disease. Curr Top Med Chem 8:28 doi:10.2174/156802608783334024

Yoshiike Y, Chui DH, Akagi T, Tanaka N, Takashima A (2003) Specific compositions of amyloid-beta peptides as the determinant of toxic beta-aggregation. J Biol Chem 278:23648-23655 doi:10.1074/jbc.M212785200

Yu WH, Kumar A, Peterhoff C, Shapiro Kulnane L, Uchiyama Y, Lamb BT, Cuervo AM, Nixon RA (2004) Autophagic vacuoles are enriched in amyloid precursor protein-secretase activities: implications for beta-amyloid peptide over-production and localization in Alzheimer's disease. Int J Biochem Cell Biol 36:2531-2540 doi:10.1016/j.biocel.2004. 05.010

Yu WH, Cuervo AM, Kumar A, Peterhoff CM, Schmidt SD, Lee JH, Mohan PS, Mercken M, Farmery MR, Tjernberg LO, Jiang Y, Duff K, Uchiyama Y, Naslund J, Mathews PM, Cataldo AM, Nixon RA (2005) Macroautophagy - a novel Beta-amyloid peptide-generating pathway activated in Alzheimer's disease. J Cell Biol 171:87-98 doi:10.1083/jcb. 200505082

Zheng L, Roberg K, Jerhammar F, Marcusson J, Terman A (2006) Oxidative stress induces intralysosomal accumulation of Alzheimer amyloid beta-protein in cultured neuroblastoma cells. Ann N Y Acad Sci 1067:248-251 doi:10.1196/annals.1354.032 